\title{
PELAKSANAAN TANGGUNG JAWAB SOSIAL PERUSAHAAN (Corporate Social Responsibility) SEBAGAI SALAH SATU INSTRUMEN DALAM PEMBANGUNAN DAERAH
}

\author{
Oleh : \\ Busyra Azheri ${ }^{1}$
}

\begin{abstract}
Given the limited funds of regional development, it is expected that CSR activities can be used as an instrument in the regional development. This requires commitment from both parties for corporate and government to formulate a clear policy, in accordance with the competencies they possess. So that CSR is not only beneficial to the corporation but also felt by the people and government in regional development.
\end{abstract}

Kata Kunci: Tanggung jawab sosial perusahaan

\section{PENDAHULUAN}

Perbincangan mengenai tanggung jawab sosial perusahaan atau Corporate Social Responsibility (selanjutnya disingkat CSR) bukanlah hal yang baru, karena istilah CSR telah berkembang sejak era 1970-an. Pada era tersebut, dicetuskan agar pemerintah melakukan intervensi yang bertujuan memperluas ruang lingkup CSR. Ruang lingkup CSR tidak hanya mencakup tanggung jawab korporasi kepada pemegang saham (shareholders), tetapi juga kepada pekerja, konsumen, pemasok. masyarakat, terciptanya udara bersih, air bersih, dan konstituen lain di mana perusahaan melakukan aktivitas usahanya. $^{2}$

Pada tahun tahun 1990-an CSR menjadi suatu gagasan yang menyita banyak perhatian, mulai dari masyarakat akademik, lembaga swadaya masyarakat (LSM), sampai para pelaku bisnis. CSR tidak hanya dilihat dari aspek kesejahteraan ekonomi (economic prosperity), keadilan sosial (social justice),

\footnotetext{
${ }^{1}$ Dosen Fakultas Hukum Universitas Andalas dan Ketua Pusat Studi Hukum Ekonomi (PSHE) FH UA.

${ }^{2}$ Douglas M. Branson, 2001, "Corporate Governance "Reform" and The New Corporate Social Responsibility", University of Pittsburgh Law Review, Vol. 62/605, page 606.
}

dan peningkatan kualitas lingkungan (environmental quality) atau dikenal juga dengan istilah Triple Bottom Line (selanjutnya disingkat TBL). Bahkan lebih jauh CSR telah bergulir sampai pada isu sertifikasi ecolabelling, yaitu sertifikasi yang diberikan kepada suatu perusahaan yang di dalam proses pembuatan produknya dari awal hingga akhir tidak berimplikasi buruk pada lingkungan dan Hak Asasi Manusia. ${ }^{3}$

Dinamika CSR tersebut, juga berdampak pada perubahan paradigma keberhasilan suatu perusahaan. Kalau selama ini ukuran keberhasilan suatu perusahaan hanya dilihat dari satu aspek yaitu keuntungan saja (profit orientate), sekarang keberhasilan suatu perusahaan juga dinilai dari penerapan CSR sebagai wujud tanggung jawab korporasi terhadap stakeholders-nya dan sekaligus sebagai upaya mewujudkan pencitraan perusahaan (corporate image atau good will). ${ }^{4}$ Perubahan paradigma ini semakin diperkuat pada saat dilangsungkannya pertemuan korporasi tingkat dunia dengan ISO/

${ }^{3}$ Sudharto P. Hadi dan FX Adi Aamekto, 2007, Dimens Lingkungan dalam Bisnis, Kajian Tanggung Jawab Sosial Perusahaan pada Lingkungan, ICSD, Jakarta, halaman 45

${ }^{4}$ Bambang Sulistiyo, 2006, Wangi Sebelum Ada Peraturan, Gatra, No. 44, Tahun XII, 20 September 2006, halaman 81 . 
COPOLCO tanggal 10 Juni 2002 di Trinidad, dimana salah satu pokok bahasannya mengenai "Corporate Social Responsibility-Concepts and Solution". Pada pertemunan tersebut, para korporasi yang tergabung dalam ISO (International Standardization Organisation) bersepakat untuk melakukan aktivitas yang berkenaan dengan kewajibannya untuk mensejahterakan komunitas lokal di sekitar wilayah usahanya dalam bentuk CSR sebagai aktivitas yang bersifat sukarela (voluntary). ${ }^{5}$ Atas dasar konsep tersebut, ISO/COPOLCO hanya memberikan pedoman (guidance) yang dituangkan dalam ISO 26000 tentang pedoman pelaporan CSR.

Namun demikian, pembuat undang-undang (legeslatifdan eksekutif) di Indonesia menyikapinya dengan mengambil sikap yang tidak populis di kalangan dunia usaha. CSR yang didasari atas etika bisnis yang sarat dengan nilai-nilai moral yang bersifat kesukarelaan (voluntary) dijadikan sebagai suatu yang bersifat keharusan (mandatory). Ketentuan ini secara eksplisit dapat dilihat dalam Undangundang Nomor 25 Tahun 2007 tentang Penanaman Modal (selanjutnya disingkat UUPM) dan Undangundang Nomor 70 Tahun 2007 (selanjutnya disingkat UUPT). Ternyata kebijakan ini ditentang oleh kalangan dunia usaha dengan berbagai alasan. Bahkan kalangan dunia usaha mengajukan permohonan pengujian terhadap Pasal 74 UUPT ke Mahkamah Konstitusi. ${ }^{6}$

Pradjoto sebagai pakar hukum perusahaan heran kenapa begitu kuatnya resistensi kalangan dunia usaha terhadap pengaturan CSR tersebut. Seolah-olah dunia usaha menutup mata terhadap serangkaian kerusakan sosial, budaya, lingkungan, dan ekonomi yang dihasilkan oleh akibat aktivitas dunia usaha. Lebih prihatin lagi, ketika beberapa pakar dan pengamat yang mengatakan hanya Indonesia yang mengatur CSR secara normatif. Mereka lupa bahwa Inggris salah satu contoh negara yang telah mengadopsi konsep CSR dalam the 2003 Corporate Responsibility Bill sebagai respon atas kegagalan penerapan White Paper on Modernising

\footnotetext{
${ }^{5}$ Arif Budimanta, dkk, 2004, Corporate Social Responsibility, Jawaban Bagi Model Pembangunan Indonesia Masa Kini, ICSD, Jakarta, halaman 45

${ }^{6}$ Mahkamah Kunstitusi menolak gugagatan kalangan dunia usaha terhadap ketentuan Pasal 74 UUPT yang dianggap bertentangan dengan Pasal 33 ayat (4) UUD 1945 melalui putusannya Nomor 53/PUU-VI/2008 tentang Permohonan Pengujian UUPT terhadap Pasal $28 \mathrm{D}$ ayat (1), Pasal $28 \mathrm{I}$ ayat (2), dan Pasal 33 ayat (4) UUD 1945
}

Company Law yang mengatur tentang transparansi atau akuntabilitas perusahaan kepada stakeholders. Article 2-nya mengatur tentang penerapan ekstrateritorial CSR di semua bidang, kewajiban perusahaan untuk melakukan konsultasi dengan stakeholders, dan membebankan kewajiban bagi perusahaan untuk menyiapkan dan mempublikasikan laporan perusahaan. Kemudian Article 6 membebankan tanggung jawab kepada perusahaan induk terhadap anak perusahaannya yang melakukan merger, akuisisi, restrukturisasi dan lainnya yang menyebabkan kerugian bagi seseorang atau lingkungan di wilayah Inggris. Sedangkan Article 7 dan 8 menekankan pada kewajiban direksi terhadap aspek sosial dan lingkungan. ${ }^{7}$

Hal yang sama juga dilakukan oleh legislasi Inggris Raya di mana investasi dana pensiun harus diperlihatkan apakah jenis investasi tersebut telah mempertimbangkan persoalan sosial, lingkungan, atau etika dalam memilih penyimpanan dan penerapan investasi. ${ }^{8}$ Pada sisi lain, Peranci juga telah mengatur CSR secara normatif melalui Nouvelles Regulations Economiques (NRE). Aturan ini mewajibkan kepada perseroan untuk melaporkan (public disclosure) bagi semua perusahaan yang telah tercatat secara nasional mengenai persoalan lingkungan, hubungan buruh domestik dan internasional, komunitas lokal, dan lain-lain. ${ }^{9}$

Mengingat CSR yang dilandasi pada aspek TBL (ekonomi, sosial, dan Lingkungan) sudah seyogianya aktivitas tersebut bisa dijadikan sebagai salah satu instrumen dalam pembangunan daerah. Permasalahannya sekarang adalah bagaimana menumbuhkan komitmen dari perusahaan dan pemahaman Pemerintah Daerah (Pemda) terhadap CSR. Apa lagi pasca diterbitkannya Peraturan Pemerintah No. 47 Tahun 2012 Tentang Tanggung Jawab Sosial Perusahaan dan Lingkungan, maka sudah seyogyanya Pemda berusaha bagaimana dana CSR dijadikan salah satu sumber dalam pembangunan daerah. Semua itu tidak terlepas dari fakta, dimana daerahdaerah yang kaya dengan sumber daya alam selalu dihadapkan dengan berbagai isu, terutama berkaitan

\footnotetext{
${ }^{7}$ Pradjoto, artikel "Tanggung Jawab Sosial Korporasi”, Kompas, 22 Juli 2007

${ }^{8}$ Illias Bantekas, 2004, "Corporate Social Responsibility in International Law", 22 Boston University International Law Review, halaman 326 .

${ }^{9}$ Ibid., halaman 326
} 
dengan ketimpangan ekonomi dan pembangunan. Atas dasar tersebut, tulisan ini mencoba membahas agar CSR dapat dimanfaatkan sebagai salah satu instrumen dalam pembangunan daerah.

\section{Penerapan CSR}

\section{Dasar Hukum Penerapan CSR}

Biladianalisa lebihjauh, pengaturan CSR dalam peraturan perundang-undangan dalam konteks Indonesia sudah tepat. Semua itu didasarkan atas transformasi nilai-nilai yang berkaitan dengan aktivitas dunia usaha dengan alasan sebagai berikut: ${ }^{10}$

a. Sebagain besar perusahaan dalam aktivitas usahanya masih menunjukan sikap mementingkan dirinya sendiri (selfish), alienasi dan/atau eklusifisme dengan lingkungan masyarakat. Sikap seperti ini harus dibuang karena perusahaan merupakan entitas sosial yang harus beradaptasi dan berinteraksi secara sosio kultural dimana perusahaan melakukan aktivitas usahanya;

b. Masih banyak perusahaan yang belum menyadari bahwa keberlangsungan atau eksistensinya amat tergantung dari faktor lingkungan dimana perusahaan melakukan aktivitas usahanya, sehingga perusahaan selain berusaha mendapatkan legitimasi dari masyarakat juga berkewajiban untuk menjaga agar tidak merusak lingkungan dimana ia melakukan aktivitas usahanya dan sekaligus wujud tanggung jawabnya kepada generasi akan datang;

c. Masih rendahnya budaya hukum (legal culture) sebagian besar kalangan dunia usaha, hal ini terlihat dari masih berkembangnya praktek KKN (korupsi, kolusi dan Nepotisme) sehubungan kewajiban yang harus dilakukannya, seperti banyaknya tunggakan pajak, belum dilakukan atau belum disetorkannya dana reklamasi, belum diterapkannya prinsip pencengahan perusakan lingkungan dan lain sebagainya. Hal itu didukung oleh lemahnya penegakan hukum (law enforcemnt);

d. Selama ini praktek dana yang dikeluarkan untuk kegiatan CSR, merupakan bagian dari biaya produksi (cost product), sehingga memberatkan

${ }^{10}$ Busyra Azheri, 2010, Disertasi, Tanggung Jawab Sosial Perusahaan (Corporate Social Responsibility) dalam Kegiatan Pertambangan di Sumatera Barat, Fakultas Hukum Universitas Brawijaya, Malang, halaman 143. konsumen sendiri. Dengan kata lain, kegiatan CSR yang dilakukan berasal dari dana masyarakat yang kemudian diserahkan lagi kepada masyarakat yang dikemas dalam bentuk kegiatan CSR dan sekaligus dijadikan sebagai ajang promosi perusahaan.

Keharusan menerapkan CSR ini juga tidak terlepas dari pengaruh globalisasi, dimana terjadinya perubahan paradigma dalam berusaha yaitu : ${ }^{11}$

a. Kalau selama ini perusahaan hanya dipandang sebagai instrumen ekonomi, namun sejalan dengan tuntutan global perusahaan harus dipandang sebagai institusi sosial.

b. Perusahaan tidak hanya mengakomodasi kepentingan shareholders, tetapi juga kepentingan stakeholders.

Pada Negara-negara maju seperti Inggris, Belanda, Kanada, dan Amerika Serikat penerapan CSR diakitkan dengan penilaian hukum oleh otoritas pasar modal yang dituangkan dalam bentuk " $p u b$ lic report", di samping penilaian dari publik sendiri. Perusahaan yang melaksanakan CSR dalam aktivitas usahanya selain mendapatkan penghargaan (reward) juga mendapatkan keuntungan kompetitif (competive advantage). Oleh karena itu, pemerintah memasukkan substansi CSR pada beberapa undang-undang diantaranya:

\section{A. Undang-undang Badan Usaha Milik Negara}

Badan Usaha Milik Negara (BUMN) sebagai salah satu pelaku ekonomi dalam sistem perekonomian nasional, disamping badan usaha milik swasta dan koperasi. BUMN ikut berperan menghasilkan barang dan/atau jasa yang diperlukan dalam rangka mewujudkan sebesar-besarnya kemakmuran rakyat. Untuk itu perlu dilakukan penataan sistem pengelolaan dan pengawasannya melalui UndangUndang Nomor 19 Tahun 2003 tentang Badan Usaha Milik Negara (UU BUMN). ${ }^{12}$ Sedangkan mengenai maksud dan tujuannya ditegaskan pada Pasal 2 ayat (1) hurufe UU BUMN adalah "turut aktifmemberikan bimbingan dan bantuan kepada pengusaha golongan ekonomi lemah, koperasi dan

\footnotetext{
${ }^{11}$ Penjelasan Yanuar Nugroho dari Business Watch Indonesia, pada saat penyerapan aspirasi pada saat pembahasan RUUPT, risalah RUUPT buku I, halaman 1037.

12 Dalam UU BUMN ditegaskan bahwa bentuk BUMN ada 2 (dua) yaitu Perusahaan Perseroan (Persero) dan Perusahaan Umum (Perum).
} 
masyarakat". Namun sebelumnya dalam Pasal 4 ayat (2) Peraturan Pemerintah (PP) Nomor 12 Tahun 1998 tentang Perusahaan Perseroan Terbatas (Persero) menegaskan bahwa Persero dengan sifat usaha tertentu dapat melaksanakan penugasan khusus untuk menyelenggarakan fungsi kemanfaatan umum.

Pemerintah mengemas keterlibatan BUMN sebagai upaya dalam rangka memperkuat program kemitraan, melalui Peraturan Menteri Negara BUMN nomor PER-05/MBU/2007 tentang Program Kemitraan Badan Usaha Milik Negara dengan Usaha Kecil dan Program Bina Lingkungan (PKBL). Dimana Pasal 2-nya menegaskan:

(1) Persero dan Perum wajib melaksanakan Program Kemitraan dan Program Bina Lingkungan dengan memenuhi ketentuan-ketentuan yang diatur dalam Peraturan ini;

(2) Persero Terbuka dapat melaksanakan Program Kemitraan dan Program Bina Lingkungan dengan berpedoman pada Peraturan ini yang ditetapkan berdasarkan Rapat Umum Pemegang Saham (RUPS).

Sedangkan mengenai sumber dananya ditegaskan dalam Pasal 9 yaitu:

(1) Dana Program Kemitraan bersumber dari:

a. Penyisihan laba setelah pajak maksimal sebesar 2\% (dua persen);

b. Jasa administrasi pinjaman/marjin/bagi hasil, bunga deposito dan/atau jasa giro dari dana Program Kemitraan setelah dikurangi beban opeasional;

c. Pelimpahan dana Program Kemitraan dari BUMN lain, jika ada.

(2) Dana Program Bina Lingkungan (BL) bersumber dari:

a. Penyisihan laba setelah pajak maksimal sebesar 2\% (dua persen);

b. Hasil bunga deposito dan atau jasa giro dari dana Program BL.

Pasal 11 menegaskan bahwa dana Program Kemitraan diberikan dalam bentuk:

a. Pinjaman untuk membiayai modal kerja dan atau pembelian aktiva tetap dalam rangka meningkatkan produksi dan penjualan; b. Pinjaman khusus untuk membiayai kebutuhan dana pelaksana kegiatan Mitra Binaan yang bersifat pinjaman tambahan dan berjangka pendek dalam rangka memenuhi pesanan dari rekanan usaha Mitra Binaan.

c. Beban pemintaan meliputi hal-hal sebagai berikut:

1. Untuk membiayai pendidikan, pelatihan, pemagangan, pemasaran, promosi, dan halhal lain yang menyangkut peningkatan produktivitas Mitra Binaan serta untuk pengkajian/penelitian yang berkaitan dengan Program Kemitraan;

2. Beban pembinaan bersifat hibah dan besarnya maksimal $20 \%$ (dua puluh persen) dari dana Program Kemitraan yang disalurkan pada tahun berjalan.

Sedangkan ruang lingkup bantuan Program BL sebagai berikut:

a. Bantuan korban bencana alam;

b. Bantuan pendidikan dan/atau pelatihan;

c. Bantuan untuk peningkatan kesehatan;

d. Bantuan pengembangan prasarana dan/atau sarana umum;

e. Bantuan sarana ibadah; bantuan pelestarian alam.

Berdasarkan penjelasan di atas, dapat ditegaskan bahwa PKBL tidak sama dengan CSR, meskipun dari aktivitasnya merupakan bagian dari aktivitas CSR. Perbedaan CSR dengan PKBL secara prinsip terlihat dari sumber pendanaannya. CSR didanai melalui komponen biaya perusahaan, sedangkan PKBL diambil dari sisa kuntungan BUMN yang ditetapkan melalui mekanisme Rapat umum Pemegang Saham (RUPS). Begitu pula dalam hal pengelolaannya, CSR langsung dikelola oleh perusahaan yang bersangkutan,'sedangkan PKBL dikelola oleh Kementerian BUMN dengan menunjuk salah satu BUMN sebagai Koordinator pada suatu daerah.

Sejalan dengan tuntutan dan kesadaran dari masing-masing BUMN, dimana dalam pelaksanaan program CSR-nya muncul istilah dana non-PKBL. Dana inilah yang digunakan oleh masing-masing BUMN untuk melakukan berbagai kegiatan di luar kegiatan PKBL yang sejalan dengan tuntutan dan kebutuhan lingkungan dimana perusahaan melakukan aktivitas usahanya. Pengelolaan dana Non- 
PKBL ini telah dimulai pada beberapa BUMN sejak tahun 2010 .

\section{B. Undang-undang Penanaman Modal}

Landasan filosofi dalam pembentukan peraturan perundang undangan di bidang ekonomi adalah Pasal 33 UUD 1945 yang mengamanatkan agar pembangunan ekonomi nasional harus berdasarkan pada demokrasi ekonomi yang mampu menciptakan terwujudnya kedaulatan ekonomi Indonesia. Prinsip demokrasi ekonomi dapat dilihat pada Pasal 33 ayat (4) UUD 1945 yang menegaskan bahwa "Perekonomian nasional diselenggarakan berdasarkan atas demokrasi ekonomi dengan prinsip kebersamaan, efisiensi, berkeadilan, berkelanjutan, berwawasan lingkungan, kemandirian, serta dengan menjaga keseimbangan kemajuan dan kesatuan ekonomi nasional". Konsep ini oleh founding fathers disebutnya dengan negara kesejahteraan (welfare state). ${ }^{13}$ Konsep ini oleh James Midgley disebut sebagai "antithetical nation". ${ }^{14}$ Penerapan prinsip demokrasi ekonomi ini dikukuhkan lebih lanjut melalui TAP MPR RI Nomor XVI Tahun 1998 tentang Politik Ekonomi dalam Rangka Demokrasi Ekonomi sebagai sumber hukum materiil.

Dilihat dari substansinya, dalam UUPM terdapat beberapa pasal yang secara substansial berkaitan dengan CSR sebagai berikut:

1. Pasal 3 ayat (2) UUPM mengenai tujuan penyelenggaraan penanaman modal dapat dilihat pada, yaitu:

a. Meningkatkan pertumbuhan ekonomi nasional;

b. Menciptakan lapangan kerja;

c. Meningkatkan pembangunan ekonomi berkelanjutan;

d. Meningkatkan kemampuan daya saing dunia usaha nasional;

e. Meningkatkan kapasitas dan kemampuan teknologi nasional;

${ }^{13}$ Pada beberapa Negara, konsep welfare state mencakup segenap proses dan aktivitas mensejahterakan warga negara dan menerapkan soistem pelayanan sosial dan skema perlindungan sosial bagi kelompok yang kurang beruntung. Lihat Edi Suharto, 2006, Negara Kesejahteraan dan Reinventing Depsos, makalah, Seminar Mengkaji Ulang Relevansi Welfare State dan Terobosan Melalui Desentralisasi Otonomi di Indonesia, Wisma MMUGM, tanggal 25 Juli 2006, halaman 5.

14 James Midgley, 2003, Growth, Redistribution, and Welfare Toward Social Invesment, dalam Dhaniswara K. Harjono, 2007, Hukum Penanaman Modal, Rajawali Press, Jakarta, halaman, 67. f. Mendorong pengembangan ekonomi kerakyatan;

g. Mengolah ekonomi potensial menjadi kekuatan ekonomi riil dengan menggunakan dana yang berasal, baik dari dalam negeri maupun dari luar negeri; dan

h. Meningkatkan kesejahteraan masyarakat.

2. Pasal 15 UUPM menegaskan bahwa setiap penanam modal berkewajiban:

a. Menerapkan prinsip tata kelola perusahaan yang baik;

b. Melaksanakan tanggung jawab sosial perusahaan;

c. Membuat laporan tentang kegiatan penanaman modal dan menyampaikannya kepada Badan Koordinasi Penanaman Modal;

d. Menghormati tradisi budaya masyarakat sekitar lokasi kegiatan usaha penanaman modal; dan

e. Mematuhi semua ketentuan peraturan perundang-undangan.

Dengan ditegaskannya CSR sebagai kewajiban bagi penanam modal, maka Pasal 15 huruf $b$ UUPM telah meletakkan landasan yuridis perubahan paradigma CSR dari bersifat voluntary menjadi mandatory. Apalagi bagi perusahaan yang tidak melaksanakannya dikenakan sanksi administratif sebagaimana dimaksud dalam Pasal 34 UUPM. Perubahan paradigma ini diperkuat dalam penjelasan umum UUPM yang menyatakan bahwa "tanggung jawab sosial perusahaan adalah tanggung jawab yang melekat pada setiap perusahaan penanaman modal untuk tetap menciptakan hubungan yang serasi, seimbang, dan sesuai dengan lingkungan, nilai, norma dan budaya masyarakat setempat".

3. Pasal 17 UUPM menegaskan;

"Setiap penanam modal yang bergerak di bidang usaha yang berkaitan dengan sumber daya alam yang tidak terbarukan diwajibkan untuk mengalokasikan sebagaian dananya untuk pemulihan lokasi usahanya sehingga memenuhi standar lingkungan hidup yang pelaksanaannya diatur sesuai dengan ketentuan peraturan perundangundangan". 
4. Pasal 34 berkaitan dengan sanksi menegaskan:

(1)Badan usaha atau usaha perseorangan sebagaimana dimaksud dalam Pasal 5 yang tidak memenuhi kewajiban sebagaimana ditentukan dalam Pasal 15 dapat dikenai sanksi administrasifberupa:

a. Peringatan tertulis;

b. Pembatasan kegiatan usaha;

c. Pembekuan kegiatan usaha dan/atau fasilitas penanaman modal; atau

d. Pencabutan kegiatan usaha dan/atau fasilitas penanaman modal.

(2)Sanksi administratif sebagaimana dimaksud pada ayat (1) diberikan oleh instansi atau lembaga yang berwenang sesuai dengan ketentuan peraturan perundang-undangan.

(3)Selain dikenai sanksi administratif, badan usaha atau usaha perseorangan dapat dikenai sanksi lainnya sesuai dengan ketentuan peraturan perundang-undangan.

Darị beberapa pasal yang terdapat dalam UUPM berkaitan dengan CSR menunjukan bahwa CSR telah ditegaskan sebagai suatu keharusan (mandatory) dalam makna liability bagi setiap investor. Bagi investor yang tidak menerapkan CSR dalam aktivitas usahanya akan dikenakan sanksi sesuai dengan ketentuan peraturan perundang-undangan yang berlaku.

\section{Undang-Undang Perseroan Terbatas}

Pasca disahkannya Undang-undang Nomor 40 Tahun 2007 tentang Perseroan Terbatas (UUPT), semakin banyak perusahaan yang secara terangterangkan menyatakan melakukan kegiatan CSR, meskipun kegiatan tersebut lebih banyak dalam bentuk charity atau philanthropy. Hal ini menunjukkan telah ada peningkatan kesadaran dunia usaha bahwa CSR merupakan suatu kewajiban perseroan. Dengan kata lain telah terjadi suatu "revolusi" terhadap prinsip CSR, dari voluntary menjadi mandatory dalam makna "legal responsibility".

CSR yang dimaksud dalam UUPT, secara terminologi ada perbedaan dengan CSR yang ada dalam penjelasan UUPM dengan menambahkan tanggung jawab sosial dẹngan lingkungan. Hal ini dapat dilihat pada Pasal 1 angka 3 UUPT menegaskan: ${ }^{15}$

${ }^{15}$ UUPT secara terminologi mengunakan rumusan "CSR plus" yaitu dengan menambahkan tanggung jawab sosial dengan lingkungan. Pada hal secara teoritis CSR mengacu pada konsep
"Tanggung jawab sosial dan lingkungan adalah komitmen perseroan untuk berperan serta dalam pembangunan ekonomi berkelanjutan guna meningkatkan kualitas kehidupan dan lingkungan yang bermanfaat, baik bagi perseroan sendiri, komunitas setempat, maupun masyarakat pada umumnya".

Lebih lanjut rumusan Pasal 1 angka 3 ini dijabarkan ke dalam Pasal 74 UUPT yang terdiri 4 (empat) ayat sebagai berikut: ${ }^{16}$

a. Pasal 74 ayat (1) UUPT menyatakan bahwa 'Perseroan yang menjalankan kegiatan usahanya di bidang dan/atau berkaitan dengan sumber daya alam wajib melaksanakan Tanggung Jawab Sosial dan Lingkungan".

Maksud dari Perseroan yang menjalankan kegiatan usahanya di bidang SDA adalah Perseroan yang kegiatan usahanya mengelola dan memanfaatkan SDA. Sedangkan Perseroan yang menjalankan kegiatan usahanya yang berkaitan dengan SDA adalah Perseroan yang tidak mengelola dan tidak memanfaatkan SDA, tetapi kegiatan usahanya berdampak pada fungsi kemampuan SDA.

b. Pasal 74 ayat (2) UUPT menyatakan bahwa "Tanggung Jawab Sosial dan Lingkungan sebagaimana dimaksud pada ayat (1) merupakan kewajiban Perseroan yang dianggarkan dan diperhitungkan sebagai biaya Perseroan yang pelaksanaannya dilakukan dengan memperhatikan kepatutan dan kewajaran".

Ketentuan ini perlu penjabaran lebih lanjut, terutama berkaitan dengan makna "kewajiban Perseroan yang dianggarkan" dan "diperhitungkan sebagai biaya Perseroan". Berdasarkan ketentuan ini, setiap Perseroan harus merancang kegiatan CSR sejak awal. Secara teoritis aturan ini sudah pasti memberatkan perusahaan, karena sejak awal perusahaan sudah mengeluarkan biaya untuk kegiatan CSR, apakah perusahaan "untung" (profit) atau "rugi" (lose out) dalam tahun anggaran yang bersangkutan, meskipun memperhatikan kepatutan dan kewajaran. Permasalahan lebih lanjut justru pada ukuran kepatutan dan kewajaran yang multi tafsir. Hal ini berbeda dengan Peraturan Menteri BUMN

Triple Bottom Line (TBL) yang mencakup aspek ekonomi, sosial dan lingkungan.

${ }^{16}$ Busyra Azheri, Op., Cit., halaman 162-166. 
Nomor KEP-05/MBU/2007 tentang Program Kemitraan BUMN dengan Usaha Kecil dan Program Bina Lingkungan, dimana dana program kemitraan dan bina lingkungan ini diambil $4 \%$ dari laba bersih setelah dipotong pajak.

Ketentuan mengenai dana yang dianggarkan untuk kegiatan CSR ini berkaitan dengan Pasal 63 UUPT menegaskan:

(1)Direksi menyusun rencana kerja tahunan sebelum dimulainya tahun buku yang akan datang.

(2)Rencana kerja sebagaimana dimaksud pada ayat (1) memuat juga anggaran tahunan Perseroan untuk tahun buku yang akan datang.

Karena CSR bagian dari rencana tahunan yang dianggarkan dari biaya perusahaan, maka CSR akan menjadi bagian dari laporan tahunan suatu perseroan sebagaimana dimaksud Pasal 66 ayat (2) poin c. Oleh karena itu perlu ada kejelasan terutama berkaitan dengan:

1. Biaya CSR sebagai bagian dari biaya perusahaan dan tidak bagian dari persentase keuntungan. Untuk itu pemerintah harus memberikan kompensasi kepada perusahaan dalam bentuk insentif pajak, sebagaimana ditegaskan dalam Pasal 6 ayat (1) Undangundang Nomor 17 Tahun 2003 tentang Pajak Pengasilan.

Apabila pemerintah tidakmemberikan insentif kepada pelaku usaha yang melaksanakan CSR, maka dana CSR akan menjadi bagian dari komponen biaya produksi (cost product) suatu perusahaan. Apabilahal ini terjadi, maka yang akan menanggung pembiayaan CSR adalah konsumen. Oleh karena itu harus ada kejelasan tentang insentif bagi perusahaan yang melaksanakan CSR.

2. CSR sebagai bagian dari rencana kerja dan laporan tahunan suatu perusahaan, untuk itu mesti ada kejelasan lembaga yang berhak melakukan pengawasan dan atau mengaudit pelaksanaan CSR. Berkaitan hal tersebut, belum ada ketentuan baik dalam undangundangan maupun PP tentang CSR, sehingga pelaksanaan CSR tergantung pada Komitmen perusahaan yang bersangkutan. c. Pasal 74 ayat (3) UUPT menegaskan bahwa "Perseroan yang tidak melaksanakan kewajiban sebagaimana dimaksud ayat (1) dikenakan sanksi sesuai dengan ketentuan peraturan perundang-undangan".

Dari rumusan tersebut di atas semakin jelas bahwa CSR merupakan suatu kewajiban bagi perusahaan, sehingga perusahaan yang tidak melaksanakan CSR akan dikenakan sanksi. Persoalan sekarang adalah belum adanya kejelasan tentang mekanisme penjatuhan sanksi dan lembaga mana yang berwenang menjatuhkan sanksi serta bentuk sanksi bagi perusahaan yang tidak melaksanakannya. Kondisi ini berdampak pada kesadaran perusahaan untuk melakukan CSR.

d. Pasal 74 ayat (4) UUPT menegaskan bahwa "ketentuan lebih lanjut mengenai tanggung jawab sosial dan lingkungan diatur dengan Peraturan Pemerintah". Persoalannya sekarang adalah PP No. 47 Tahun 2012 yang telah ditunggu 5 (lima) tahun tidak mengatur lebih lanjut tentang subsantsi pelaksanaan CSR. PP ini hanya bersifat penegasan bahwa CSR merupakan suatu kewajiban bagi perusahaan yang bergerak dan atau berhubungan dengan sumber daya alam.

\section{Penerapan CSR oleh Kalangan Dunia Usaha}

Secara esensial CSR merupakan inti dari etika bisnis, dimana suatu perusahaan tidak hanya mempunyai kewajiban ekonomis dan legal kepada pemegang saham (shareholders), tetapi perusahaan juga mempunyai kewajiban terhadap pihak lain yang berkepentingan (stakeholders). Semua itu tidak lepas dari kenyataan bahwa suatu perusahaan tidak bisa hidup, beroperasi dan bertahan serta memperoleh keuntungan tanpa bantuan dari berbagai pihak. ${ }^{17}$ Kepedulian perusahaan ini sendiri terlihat dari komitmen perusahaan untuk mempertanggungjawabkan segala dampak dari aktivitas usahanya dalam dimensi ekonomi, sosial, dan lingkungan (TBL). Bagi perusahaan yang konsisten menerapkan CSR dalam aktivitasnya, dalam jangka panjang akan mendapatkan keuntungan dalam bentuk kepercayaan dari stakeholders-nya (corporate image). Kondisi ini telah menjadi perhatian yang serius dari

${ }^{17}$ Erni R. Ernawan, 2007, Business Ethics, Alfabeta, Bandung, halaman 110 
kalangan dunia usaha baik domestik maupun internasional. Karena ada korelasi positif antara perusahaan yang menerapkan CSR dengan apresiasi masyarakat. Oleh karena itu CSR tidak lagi dianggap sebagai "cost product", melainkan sebagai investasi jangka panjang bagi perusahaan.

Selain tuntutan internal, CSR juga tidak terlepas dari wujud pertanggungjawaban perusahaan atas dampak lingkungan sebagai akibat aktivitas usahanya. Fakta empiris yang tidak bisa dinafikan adalah begitu banyak perusahaan yang telah merusak tatanan lingkungan dan struktur sosial masyarakat. Seperti kasus lumpur Lapindo di Porong, konflik masyarakat Papua dengan PT Freeport Indonesia, konflik masyarakat Aceh dengan Exxon Mobile di Arun, pencemaran lingkungan oleh Newmont di Teluk Buyat, dan lain sebagainya.

Berdasarkan hasil surve yang dilakukan Suprapto dan Siti Adiprigadi Adiwoso pada tahun 2005 terhadap 375 perusahaan di Jakarta, ${ }^{18}$ menunjukkan bahwa 166 (44,27 \%) perusahaan menyatakan tidak melakukan kegiatan CSR dan 209 (55,75\%) perusahaan melakukan kegiatan CSR. Sedangkan bentuk CSR yang dilakukan adalah, pertama; kegiatan kekeluargaan (116 perusahaan), kedua; sumbangan pada lembaga agama (50 perusahaan), ketiga; sumbangan pada yayasan sosial (39 perusahaan), keempat; pengembangan komunitas (4 perusahaan). Survei ini juga mengungkapkan bahwa CSR yang dilakukan oleh perusahaan amat tergantung pada keinginan dari pihak manajemen perusahaan. Sedangkan hasil survei Kompas tentang penerapan CSR tahun 2007 menunjukkan bahwa kegiatan CSR hanya dilakukan $\pm 30 \%$ dari keseluruhan perusahaan yang beroperasi di Indonesia, dan kegiatannya sendiri lebih terfokus pada kedermawanan (philanthropy) dan kemurahan hati (charity) dalam rangka membantu korban bencana alam. ${ }^{19}$

Dari hasil penelitian dan surve tersebut, terlihat bahwa penerapan CSR lebih bersifat spontanitas dan tidak terencana dengan baik serta upaya untuk meredam tututan dan resistensi masyarakat. Bahkan kegiatan CSR tidak lebih dari memperlihatkan

${ }^{18}$ Suprapto \& Siti Adipringadi Adiwoso, 2006, Pola Tanggung Jawab Sosial Perusahaan Lokal di Jakarta. Majalah Galang vol.1, No. 2, Januari 2006.

${ }^{19}$ Harian Kompas, Hasil Surve CSR, 4 Agustus 2007. empati terhadap musibah yang dialami masyarakat. Lebih disesali lagi adalah bahwa dibalik kegitan CSR tersebut, terselip misi terselubung yang berkaitan dengan promosi perusahaan. Indikasi ini terlihat dari ekpose kegiatan CSR melalui media cetak dan elektronik. Kebijakan seperti inilah yang dilakukan oleh sebagian besar kalangan dunia usaha sebagai wujud CSR mereka.

Terlepas dari fakta tersebut, penerapan CSR di kalangan dunia usaha dipengaruhi oleh beberapa faktor, antara lain: ${ }^{20}$

a. Komitmen pimpinan perusahaan

Perusahaan yang pimpinannya tidak tanggap dengan masalah-masalah sosial dan lingkungan (since of social and enveronment), kecil kemungkinan akan mempedulikan aktivitas CSR.

b. Status kepemilikan dan kemapanan perusahaan Perusahaan besar atau asing dan BUMN yang mapan lebih mempunyai potensi memberikan kontribusi ketimbang perusahaan kecil dan belum mapan. Namun, bukan berarti perusahaan menengah, kecil, dan belum mapan tersebut tidak dapat menerapkan CSR, semuanya amat tergantung pada corporate culteru yang mau mereka kembangkan.

c. Regulasi dan sistem perpajakan

Semakin meluasnya regulasi dan penataan pajak akan membuat semakin kecil ketertarikan perusahaan untuk memberikan donasi dan sumbangan sosial kepada masyarakat. Sebaliknya, semakin kondusif regulasi dan atau semaikin besar insentif pajak yang diberikan, akan lebih berpotensi memberi semangat kepada perusahaan untuk berkontribusi kepada masyarakat.

\section{III.CSR Sebagai Salah Satu Instrumen Pem- bangunan Daerah}

Mengingat keterbatasan sumberdana dalam pembangunan suatu wilayah, pemerintah berdasarkan kewenangan yang dimilikinya bisa menjadikan CSR sebagai instrumen dalam pembangunan daerah. Agar penerapan CSR memberikan dampak positifbersifat jangka panjang bagi pembangunan daerah. Berkaitan dengan hal tersebut, sudah seyogianya Pemda lebih memposisikan diri sebagai:

${ }^{20}$ Busyra Azheri, Op., Cit., halaman 429-430. 
a. Regulator

Dengan keluarnya PP No. 47 Tahun 2012 sebagaimtindak lanjut dari Pasal 74 ayat (4) UUPT, pemerintah daerah (Pemda) dapat mengatur penerapan CSR sedemikian rupa yang dituangkan dalam bentuk Peraturan Daerah (Perda). Regulasi dimaksud harus dirumuskan sedemikian rupa dengan mengedepankan aspek percepatan pertumbuhan wilayah dan masyarakat dalam makna holistik. Dengan kata lain, Pemda tidak mengedepankan aspek pendapatan daerah, tetapi memberikan berbagai insentifdan kemudahan dalam rangka pertecapatan pertumbuhan ekonomi dan pengembangan wilayah.

b. Partisipan

Pemerintah sebagai bagian dari stakeholders suatu perusahaan bisa berpartisipasi secara aktif dengan merumuskan suatu program yang berkaitan dengan penerapan CSR dalam lingkup triple bottom line (aspek ekonomi, sosial dan lingkungan). Program tersebut ditawarkan kepada kalangan dunia usaha, terutama perusahaan yang beroperasi pada wilayah tertentu. Kebijakan seperti ini telah dilakukan oleh pemerintah Kanada, terutama dalam pembanguan berbagai fasilitas umum.

c. Fasilisator

Mengingat keterbatasan yang suatu perusahaan, sudah seyogianya pemerintah bisa bertindak sebagai fasilisator dalam penerapan CSR dengan mempertemukan para stakeholders sehubungan dengan rencana penerapan suatu kegiatan CSR.

Mengingat ruang lingkup CSR begitu luas, sedangkan kalangan dunia usaha memiliki keterbatasan dalam penerapannya. Oleh karena itu dalam regulasi (Perda) yang dibuat oleh Pemda harus membuka peran aktif dari masyarakat dan LSM, yaitu dengan cara memberikan informasi, saran, dan masukkan atau pendapat untuk menentukan program yang akan dilakukan. Dengan demikian kegiatan CSR akan berkontribusi pada pembangunan daerah. Dalam konteks ini, CSR lebih dimaknai sebagai investasi jangka panjang bagi perusahaan.

Berkaitån dengan pelaksanaan CSR tersebut, pada bulan September tahun 2004, International Organization for Standardization (ISO), sebagai induk organisasis standardisasi internasional berhasil menghasilkan panduan dan standardisasi untuk CSR yang diberi nama ISO 26000 : Guidance Standard on Social Responsibility. ISO 26000 mengartikan CSR sebagai tanggung jawab suatu organisasi yang atas dampak dari keputusan dan aktivitanya terhadap masyarakat dan lingkungan, melalui perilaku yang transparan dan etis, semua itu terlihat dari: ${ }^{21}$

a. Konsisten dengan pembangunan berkelanjutan dan kesejahteraan masyarakat;

b. Memperhatikan kepentingan dari para stakeholder;

c. Sesuai hukum yang berlaku dan konsisten dengan norma-norma internasional; dan

d. Terintegrasi di seluruh aktivitas organisasi, baik kegiatan, produk maupun jasa.

Selain itu, apabila Pemda membuat regulasi seyogianya memperhatikan 7 (tujuh) isu pokok sebagaimana tercantum dalam ISO 26000 yaitu sebagaiberikut:

a. Pengembangan masyarakat;

b. . Konsumen;

c. Praktek kegiatan institusi yang sehat;

d. Lingkungan;

e. Ketenagakerjaan;

f. Hak Asasi Manusia;

g. Organizational Governance (Organisasi Kepemerintahan).

Agar penerapan CSR tersebut efektif, maka ke 7 (tujuh) isu pokok ISO 26000 harus terintegrasi dalam aktivitas perusahaan. Untuk itu perlu diperhatikan prinsip-prinsip dasar CSR dalam ISO 26000 yang bisa dijadikan dasar dalam pembuatan keputusan dan kegiatan CSR meliputi:

a. Kepatuhan kepada hukum;

b. Menghormati instrumen/badan-badan internasional;

c. Menghormati stakeholders dan kepentingannya;

d. Akuntabilitas;

e. Transparansi;

f. Perilaku yang beretika;

g. Melakukan tindakan pencegahan;

h. Menghormati dasar-dasar hak asasi manusia.

${ }^{21}$ Ibid, halaman 120-121 
Berkaitan dengan peran Pemda dalam upaya menjadikan kegiatan CSR sebagai salah satu intrumen dalam pembangunan daerah, kita dapat berpedoman pada kebijakan yang diterapkan oleh Kanada sebagai salah satu negara yang mempunyai perhatian yang besar terhadap CSR, di mana pada bulan Desember 2006 pemerintah dan parlemen bersama kalangan industrinya berusaha menetapkan beberapa strategi berkaitan dengan penerapan CSR sebagai berikut: ${ }^{22}$

a. Perlindungan Lingkungan (Environmental Protection)

Industri Kanada berusaha mendorong perusahaan berkenaan dengan praktek perlindungan lingkungan melalui beberapa lembaga, seperti untuk strategi pembangunan berkelanjutan dengan melibatkan Industrial Technologies Office, Lean Manufacturing, and Technology Roadmaps. Ketentuan perlindungan lingkungan ini telah menjadi suatu persyaratan baik berkenaan dengan perizinan maupun dengan lembaga keuangan.

b. Pengelolaan Perusahaan(Corporate Governance) Pemerintah Kanada tidak lagi terlibat dalam pengelolaan perusahaan, semuanya diserahkan pada asosiasi perusahaan itu sendiri. Ketentuan ini diatur dalam amandemen Canada Business Corporations Act pada tahun 2001. Sedangkan pertanggungjawabannya tetap di bawah pemerintah, baik pada tingkat pusat, provinsi maupun lokal. Kondisi ini berdampak positif bagi perkembangan dan kemampuan berkompetisi antara perusahaan.

c. Praktek Manajemen Sumber daya Manusia (Human Resource Management Practices)

Kalangan industri Kanadamempunyai perhatian yang cukup untuk meningkatkan praktek manajemen sumber daya manusia. Hal ini terlihat dari program pelatihan dalam rangka meningkatkan keterampilan dan keahlian pekerja/buruh sehingga dapat diterapkan dalam dunia usaha.

d. Promosi dan Perlindungan Konsumen (Promotion and Protection of Consumer)

Melalui serangkaian aktivitas industri Kanada memastikan terwujudnya suatu kompetisi yang

${ }^{22}$ Ibid, halaman 184-185 adil dan pasar yang efisien untuk bisnis dan konsumen. Dalam hal ini Office of Consumer Affairs (OCA) dan Competition Bureau memainkan peran penting. OCA menyediakan jasa dan produk untuk meningkatkan kesadaran konsumen. Berdasarkan keikutsertaan OCA dalam kelompok kerja ISO's untuk perlindungan konsumen pada pasar global, OCA tengah menyelidiki pengembangan standard internasional untuk CSR. Sedangkan Competition Bureau mengurus dan mengatur mengenai penegakan hukum yang berkaitan dengan ketentuan Competition Act, Consumer Packaging and Labelling Act, and the Textile Labelling Act.

e. Pengembangan Komunitas (Community Development)

Berkaitan dengan program yang amat kental dengan dimensi sosial dan kemanfaatannya, baik bagi Kanada sendiri, maupun negara lain. Kegiatan ini dilaksanakan dalam bentuk pemberian komputer untuk sekolah, pelayanan kesehatan masyarakat, pemberian bea siswa, magang dan lain sebagainya.

f. Kesehatan dan Keselamatan Kerja (Health and Safety)

Masalah kesehatan dan keselamatan kerja dalam lingkungan industri Kanada mendapat tempat tersendiri. Setiap perusahaan harus membuat suatu kebijakan melindungi seluruh pekerja/buruhnya bekerja sama dengan industri farmasi dan asuransi. Sejalan dengan perkembangan teknologi informasi dan telekomunikasi, dikembangkan program "telehealth". Program ini memberikan berbagai informasi dan kemudahan dalam pelayanan kesehatan melalui teknologi multi media.

Perlu juga diperhatikan bahwa CSR tidak hanya menjadi kewajiban perusahaan yang menghasilkan produk barang dan jasa, tetapi juga dilaksanakan oleh perusahaan yang bergerak di bidang jasa dan portofolio. Berkaitan penerapan CSR, dimana berdasarkan hasil penelitian dewan ilmu sosial dan riset kemanusiaan (Social Sciences and Humanities Research Council (SSHRC)) menunjukkan bahwa bisnis perbankan menerapkan CSR dalam bentuk menyediakan pelatihan dan program magang bagi mereka yang baru lulus perguruan tinggi, pemberian 
bantuan dana operasional untuk kegitan pelatihan dan pengembangan bisnis serta pengembangan berbagai aktivitas kemasyarakatan.

Perkembangan pendekatan kebijakan yang diambil oleh pemerintah terhadap penerapan CSR semakin luas, mencakup aspek informasi, ekonomi, dan instrumen regulasi lainnya. Bahkan aktivitas CSR diintegrasikan menjadi tindakan kebijakan publik, meskipun tidak dinyatakan sebagai CSR secara tegas antara lain: ${ }^{23}$

a. Standar minimum berkaitan dengan perlindungan lingkungan, kesehatan dan keselamatan, serta hubungan ketenagakerjaan;

b. Keharusan membuat laporan tahunan yang berkaitan dengan tanggung jawab publik yang digambarkan sebagai kontribusi perusahaan terhadap masyarakat dan perekonomian negara (Kanada), sosial dan budaya, dan lain sebagainya;

c. Instrumen fiskal yang dapat mendorong CSR, seperti pengurangan dan kredit pajak untuk perusahaan;

d. Pelatihan bidang pendidikan dan dukungan jaringan profesional;

e. Prakarsa mengumpulkan informasi untuk membangunan pengetahuan berdasar CSR.

f. Program bersifat fakultatif berkaitan dengan pendaftaran capaian emisi atau efek rumah kaca dan lain-lain.

g. Pada tahun 1995, berdasarkan amanat Auditor General Act di bentuklah Komisi Lingkungan dan Pembangunan Berkelanjutan. Komisi ini diharapkan mampu melahirkan strategi pembangunan berkelanjutan untuk setiap 3 (tiga) tahun sekali.

Selain itu Dewan Perwakilan Rakyat Kanada (Board of Canada) juga menbentuk badan independent yang khusus menangani CSR yaitu Canadian Business for Social Responsibility (CBSR). Badan ini diberi wewenang yang luas, mulai dari mensosialisasikan CSR kepada berbagai asosiasi dunia usaha, merumuskan kebijakan, memberikan penghargaan (CSR award), menerapkan standar mutu sesuai dengan ketentuan internasional berkaitan dengan aspek CSR, dan berbagai kebijakan lainnya.
Khusus dalam penerapan CSR, CBSC memberikan kebebasan kepada perusahaan untuk melaksanakan CSR didasarkan atas prinsip self assesment and benchmark. Dengan demikian perusahaan bisa dengan leluasa menerapkan CSR yang didasarkan atas kebutuhan lingkungan dimana perusahaan beropersi. Semua itu terlihat dari laporan yang bersifat suatu keharusan yang mengacu pada standar ISO, OECD, dan OHSA.

\section{Penutup}

Berdasarkan uraian di atas dapat disimpulkan beberapa hal yang berkaitan dengan penerapan CSR dalam rangkan pembangunan daerah sebagai berikut:

1. Secara normatif penerapan CSR bagi kalangan dunia usaha telah dilandasi oleh dasar hukum yang kuat. Bagi BUMN telah diatur sedemikian rupa ketentuan yang mengaturnya, mulai pada tataran Undang-undang Nomor 19 Tahun 2003 tentang Badan Usaha Milik Negara kemudian ditindaklanjuti dengan Peraturan Menteri BUMN Nomor PER-05/MBU/2007 tentang Program Kemitraan Badan usaha Milik Negara dengan Usaha Kecil dan Program Bina Lingkungan. Sedangkan bagi kalangan dunia usaha pada umumnya telah diaturmengenai kewajiban menerapkan CSR ini dalam Undang-undang Nomor 25 Tahun 2007 tentang Penanaman Modal dan Pasal 74 Undang-undang Nomor 40 Tahun 2007 tentang Perseroan Terbatas jo PPNo.47 Tahun 2012 tentang Tanggung Jawab Sosial Perusahaan dan Lingkungan.

2. Untuk bisa menjadikan CSR sebagai salah satu instrumen dalam rangka pembangunan daerah, pemerintah daerah harus dapat memposisikan dirinya baik sebagai regulator, partisipan, dan fasilisator. Ketiga peran tersebut harus dilakukan secara simultan dengan mengedepankan paradigma pembangunan wilayah dengan meminta komitmen pada perusahaan dalam penerapan CSR tersebut.

\footnotetext{
${ }^{23}$ Ibid., halaman 188
} 


\section{DAFTAR PUSTAKA}

Arif Budimanta, dkk, 2004, Corporate Social Responsibility, Jawaban Bagi Model Pembangunan Indonesia Masa Kini, ICSD, Jakarta.

Bambang Sulistiyo, 2006, Wangi Sebelum Ada Peraturan, Gatra, No. 44, Tahun XII, 20 September 2006;

Busyra Azheri, 2010, Disertasi, Tanggung Jawab Sosial Perusahaan dalam Bidang Pertambangan di Sumatera Barat, Fakultas Hukum Universitas Brawijaya, Malang;

Dhaniswara K. Harjono, 2007, Hukum Penanaman Modal, Rajawali Press, Jakarta;

Douglas M. Branson, 2001, "Corporate Governance "Reform" and The New Corporate Social Responsibility", University of Pittsburgh Law Review, Vol. 62/605;

Edi Suharto, 2006, Negara Kesejahteraan dan Reinventing Depsos, makalah, Seminar Mengkaji Ulang Relevansi Welfare State dan Terobosan Melalui Desentralisasi Otonomi di Indonesia, Wisma MMUGM, tanggal 25 Juli 2006;

Erni R. Ernawan, 2007, Business Ethics, Alfabeta, Bandung;

Harian Kompas, Hasil Surve CSR, 4 Agustus 2007;

Illias Bantekas, 2004, "Corporate Social Responsibility in International Law", 22 Boston University International Law Review;
James Midgley, 2003, Growth, Redistribution, and Welfare, Toward Social Invesment;

Kristina K. Hermann, 2004, "Corporate Social Responsibility and Sustainable Development: The European Union Initiative as a Case Study", Indiana Journal of Global Legal Studies, Vol. 11/2004;

Pradjoto, artikel "Tanggung Jawab Sosial Korporasi”, Kompas, 22 Juli 2007

Putusan Mahkamah Kunstitusi terhadap gugagatan kalangan dunia usaha terhadap ketentuan Pasal 74 UUPT yang dianggap bertentangan dengan Pasal 33 ayat (4) UUD 1945 melalui putusannya Nomor 53/PUU-VI/2008 tentang Permohonan Pengujian UUPT terhadap Pasal $28 \mathrm{D}$ ayat (1), Pasal 28 I ayat (2), dan Pasal 33 ayat (4) UUD 1945.

Sudharto P. Hadi dan FX Adi Aamekto, 2007, Dimensi Lingkungan dalam Bisnis, Kajian Tanggung Jawab Sosial Perusahaan pada Lingkungan, ICSD, Jakarta;

Suprapto \& Siti Adipringadi Adiwoso, 2006, Pöla Tanggung Jawab Sosial Perusahaan Lokal di Jakarta. Majalah Galang vol.1, No. 2, Januari 2006. 